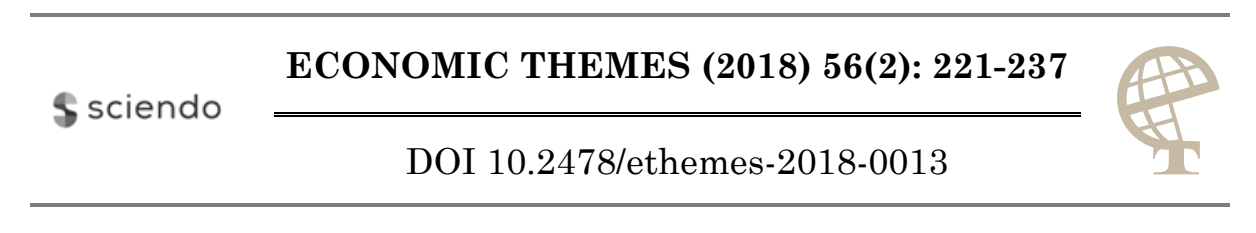

\title{
METHODS AND TECHNIQUES OF QUALITY PROCESS IMPROVEMENT IN THE MILK INDUSTRY IN THE REPUBLIC OF SERBIA
}

\author{
Milan Mihajlović \\ University Educons, Faculty of business economics, Sremska Kamenica - \\ Novi Sad, Serbia \\ $\triangle$ mihamilan@gmail.com
}

UDC

637.13:005.6

(497.11)

Review

paper
Apstrakt: A long standing presence of process orientation in economic theory and practice reflects its use for achieving the goals of the company and its stakeholders. However, this does not mean that there is no space for improvement in this area. On the contrary, the context in which companies do business is changing significantly, even on a daily basis, and therefore it is necessary to look for new ways for process improvement in order to meet not only current, but also future needs of the consumers. The main aims of the study are to define concepts related to business processes and business process management, and to research the application of methods and techniques of a continuous improvement of processes and management systems in general. The aim is also to research the application of methods and techniques for quality process improvement in milk production companies in the Republic of Serbia, with the starting hypothesis that quality process improvement directly influences the competitive position of the company. Relevant literature has been used for the theoretical part of the study dealing with process management and quality management, while a structural questionnaire on which the whole research is based has been used for the empirical part of the study. Based on the data analysis it can be concluded that in the milk production companies in the Republic of Serbia there is a dominant use of the method based on the PDCA cycle for business quality improvement

Received:

25.04.2018

Accepted:

30.05.2018
Ključne reči: process, quality, PDCA cycle, process management, continual improvement, process orientation...

Jel classification: M21, L22 


\section{Introduction}

In contemporary society, when companies are faced with global competition, there is a strong tendency to find new ways for improving performances through the increased product and process quality, and also through reducing business expenses. In order to identify new ways more easily, many companies accept process orientation as a necessity and a condition for a successful business. Process orientation facilitates the identification of activities and tasks that lead to value creation, providing a more positive effect on business through quality, expenses and time of the realization process, and that is finally reflected on the company`s competition. While doing so, the quality is emphasised as a determinant of competition whose effects can be seen in its effectiveness and efficiency. The starting point is, in this regard, that a continual quality improvement of business processes, based on the concept of quality management, is a condition for meeting both internal and external consumers' expectations.

\section{Process orientation}

Process orientation is a business approach and a way of thinking with a focus placed on the process, as a collection of mutually interrelated activities that transform inputs into outputs. Seeing a company as a system of integrated processes leads to many changes. Firstly, the businesses are not grouped according to their relationships, as in the case of traditional (functional) organisation. The employees performing the actual process are gathered in a process team with a full responsibility for the whole process. Finally, teams are in charge of the process owner. (Galbraith, 2002, pg. 38) Formed teams encourage interfunctional cooperation, and thus classical rigid organisational units disappear, but also the barriers between them and that is one of the main disadvantages of functional organisational structure. Emphasising team roles and interfunctional cooperation increases the possibility of making decisions by lower management levels while higher management levels are excluded from making many tactical and operational decisions. This leads to increased organisational capacity of decision-making, reduced number of management levels, prompt response to changes, and therefore to increased efficiency and flexibility of a company.

Process orientation is not a synonym for process organisational structure. It is the first step towards a process-oriented organisational structure. On the other side, process orientation cannot be analysed from a wider aspect than a process organisation since the organisation can reach a certain level of process maturity without being a formally and horizontally arranged (Bosilj Vukšić et. al. 2006, pp. 8). 
Process orientation represents an effort to incorporate business process management into the organisational structure and strategic organisation planning so that performance improvement through business process management would become a part of a company`s strategy (Ahmadi et.al. 2015 pp. 600).

\section{Business process management}

The concept of business process management is used in order to describe the organisation which emphasises management of interrelated processes thus accomplishing the management of the entire value chain of a product/service. In other words, business process management is defined as a holistic approach to management focusing on the identification, defining, implementation, measurement, monitoring, analysis and a continual improvement of business processes (Radosavljević M. 2015)

M. E. Porter can be regarded the founder of the business process management. In his work Competitive Advantage: Creating and Sustaining Superior Performance published in 1985, he introduced the concept of a company as a value chain. Value chain is seen as a series of business processes, from market research, defining customers ' demands, developing and designing a new product, production and selling to the buyer and activities after the selling. According to Porter (1985) all business processes, based on the value creation for the company, can be divided into primary and secondary ones. Or, in other words, into main processes and support processes (subprocesses) that also must be included into the unique value chain since they must be undertaken.

On the other hand, starting from the general systems theory according to which a company can be regarded as an open system that is in constant interaction with its surroundings, it may be said that a company is a part of a larger system in which, together with other related companies, comprises a business network, or, more popularly, a supply chain. Similarly to a company level, at network level relationships between companies are based on their business processes. The process orientation approach includes not only companies, but also supply networks or chains and it is the result of more common competition relationships between supply chains and not between individual companies (Radosavljević, 2015, pp. 408-409)

Business Process Management (BPM) is a systematic approach to business improvement based on process shaping, measuring, analysing, improving and managing. Business process management relies on the business approach of improving changes due to business process improvement in order to meet the business goals. These changes include the whole life cycle of a process: from process defining and modeling to performing, analysing and optimising processes. 
The first step in business process management involves defining business processes. The business process owners have the most important role at this stage since they possess business demands and available resources. The next step is business process modelling and it involves gathering enough information in order to understand how a process functions and then to formalise the business process in a business process flow diagram. A business process is then implemented within a company and the key performance indicators (KPI) of the company are monitored. Received information are then analysed in order to identify unexpected behaviour, non-optimised expenses, and then, if it is necessary, the process is being optimised.

\section{Process management - the basis of quality management}

It is clear from the previous text that satisfying customers' needs, process orientation, team work and continual improvement of process quality are some of the basic characteristics of process orientation. If these characteristics are compared to the key principles of quality management (customer focus; leadership; people involvement; process approach; improvement; factual approach to decision making; systematic approach to management) it can be seen that there are certain similarities and even complementarity between these two approaches.

The principles of quality management represent a group of rules according to which an organisation is guided and based on which processes are managed within the organisation, with the goal of meeting all customers' demands with a continual performance improvement.

The principles of quality management according to the newest version of standard series ISO 9000:2015 are: (SRPS ISO 9000:2015 pg. 12-22)

- customer focus,

- leadership,

- engagement of people,

- process approach,

- improvement,

- evidence-based decision making,

- relationship management.

Process approach enables a better understanding of interrelated processes as a system and their management. In that way it contributes to the effectiveness and efficiency of the organisation in achieving its anticipated results. This approach enables organisation to manage the relationships and interdependence among processes in the system so that total organisational performance can be improved. The process approach also increases organisational ability to target its efforts on performing key processes and on a more efficient use of resources. 
Although each process possesses features characteristic for the organisation in which it is realised, as well as characteristics that differentiate it in relation to other processes, there are also certain general elements and features that can be observed in each business process (Jeston, 2014). These elements are shown next.

Business owner. Business owner is responsible for the realisation of the process and its performances and has the authority to make or supervise process changes. He is responsible for the final result and he will follow the process from the beginning until the end, and there are no possibilities for switching responsibility from one function to the other. It is important that a process owner has adequately 'high' position in the company to see how the process corresponds to higher goals, i.e. to which extent it contributes to the realisation of the company`s goals (Anđelković Pešić, 2010).

Process map. Process mapping enables process scanning with the aim to find out the current realisation of the process (flow process diagram). Maps represent means of communication and visual support to the process procedure. The first step in process identification is determining border points. Border points enable identification of the entry and exit parts of the process (where the process begins and where it ends). Those are actually its inputs and outputs. Output process is intended for an intern or extern customer and, in order to meet his demands with its characteristics, it is necessary to define and control process inputs since they can be the output of a previous process. Their clear identification enables defining limitations and aims of the activity which facilitates assigning ownership and management of the interactions between different processes and subprocesses.

Transformation within the process. Process is a transformation of the input set into wanted outputs in the form of products, services, information, or generally, results. This transformation is achieved due to certain activities that are, in fact, a part of the process. Thus, a transformation through a set of connected work activities provides an output whose value is higher than the one of the used inputs and, most importantly, has a certain value for the users/customers.

Control points. Control points represent key process points in which it is necessary to perform inspection or verification. They can occur before (they are related to stage product control, i.e. control of certain activities or operations during which managers can see the process) or after the process realization (they refer to the control of process results and they are a significant factor of the company's reputation since they prevent delivery of poor quality results) (Bošković, Anđelković Pešić, 2011).Information received in the control point can be used for canceling the process due to its incompatibility with the quality or the customer standards or for the process improvement. The process which does not clearly define control points will be able to respond only to problems but not to prevent them proactively. Even though it may seem that a well-designed process 
should not demand an extensive application of control points, it is the control that ensures an efficient process. The control is used so that the process stays on the right track.

Process user. It is necessary for each process to identify customer demands that have to be met. That can be the next work team along the line; or another department of the organisation or even another factory within the same company. Or, it can be a more classical example of the user, the end user. Demands may be set up within the company, by internal users, as well as by external users. Although all processes are not key process, or directly connected to the demands of the external users, each one is guided by the notion that the next process is the 'internal user' that needs to be served.

Feedback. In other to make sure if the flow and the result of the process meet users ' demands for effectiveness and efficiency, it is necessary to use certain performance measures. These measures modify or coordinate transformational activities in order to achieve and maintain certain output attributes. Therefore, the feedback is provided through communication channels and established performance measures. Performance measures define expectations for internal and external users and ensure that their demands are efficiently met. Some of the measurements that are used are: (Institute of Management Accountants, 2000): compliance measures (degree to which output meets the requirements), responsiveness measures (time from the process activation until the results), level of service measures, process reliability measures (the ability to create the same level and quality of the output over the time), cost measures, etc.

Repetitiveness. Repetitiveness shows that processes are performed many times in the same way. Therefore, it is necessary to make a difference between process type and process instance (Bider, 2005). The concept process type is used when we talk about a process in general, for example a selling process or decision making process. A model is created for each process type in the company and according to it all its instances should be performed. The concept process instance is used to point to a specific process such as, for example, sale processing that is related to a specific customer. Each process instance represents a process that is performed in the same way.

Hierarchy (complexity). A business process can be seen as a complex entity that has a certain structure, or a set of sub processes and activities that lead to goal achieving. It is common to identify sub processes within a process as sets of activities that lead to achieving an activity as a group of work tasks with a certain goal and work tasks (operations) of each activity individually. This leads to a possibility of desegregation of a certain process into hierarchically lower ones.

Executives. Activities as parts of business processes are executed by people or by machines. Employees may perform activities independently or with the help of informational systems, or they can even be completely automated. The 
presence of a larger number of people as a subjective factor in the process leads to a greater uncertainty in the process execution since the presence of a subjective factor can affect the process objectivity, or its standardized 'behavior'.

In order to have a successful integration attempt of all organisational units into a unique system that can meet the demands of the customers and other stakeholders, all above mentioned elements must be present. This is the reason why business process management is shown as a system and platform for connecting business processes, business flows and informational technology as a support to the business process realization (Dumas et. al, 2013).

\section{Methods and techniques of quality process improvement}

Due to the evolution of process approach and of quality management, many methods and techniques of quality process improvement have been developed. This chapter will show some of the most significant ones.

\subsection{TQM and quality process improvement}

The concept of the TQM total quality management includes three basic processes that are interrelated and are essential for market survival and for a long term development of the company: (George, Weimerskirch, 1994)

- Strategic political management;

- Business process management:

- Continual improvement process.

Strategic political management is a vertical, base process of total quality management. The main task of the management is to broaden perspective and to define a vision and mission and to set organisational goals. Strategic business management transforms strategic goals into operative ones through specific actions realised in business processes. It is a process performed from the top to the bottom. In this way organisational management dedicated to total quality management defines quality politics, gives directions and initiatives regarding the quality and reexamines the business quality.

Business process management is a horizontal, base process of total quality management. It starts from determining consumer's needs and demands, then ensures that they are met through appropriate processes and finishes with a product/service that satisfies consumer's needs. In this way a value chain is formed that starts and finishes with the customer. In order to understand this better it is necessary to make a difference between internal and external customers. An external customer buys a final product/service that has meet his own demands, while an internal customer takes other employers ' process outputs, performs business operations according to certain procedures and gives the output 
of his business process which becomes an input for the next employee/customer. Management of a such formed value chain is a base for the third base process of total quality management, the continual improvement process.

Continual improvement process is a cyclic, base process of total quality management in which all employees of all levels take part. The process starts with determining possible improvement forming a detailed plan with clear goals. Since a company`s business includes many processes, it is necessary to focs on 'key processes', i.e. those that have the greatest influence on satisfying customers' needs, cost expenses, quality, etc. The process continues with development and solution choice that is necessary to implement and thus finish the flow directed from the top to the bottom. Implementation of the chosen solution is reaized by teams on lower organisational levels who transfer information gathered by following and measuring implemented solutions as well as suggestions for further improvements to the organisational top management thus ending a cyclic movement of continual improvement processes.

Dahlgaard-Park (2011), believes that TQM has shown certain signs of losing its attractiveness in the most developed world economies since the beginning of this century. Therefore, concepts such as Business Excellence, Six Sigma and Lean become dominant even though the content of these methods can be found within TQM.

\subsection{Excellence models and quality process improvement}

National awards for excellence offer guidelines for organisational business improvements, promoting new tendencies and awarding those who choose business excellence. Organisations accept and adjust to certain models for measuring performances in order to reach values that will be awarded for quality. Continual business process improvement as well as a constant customer satisfaction increase enables organisations to reach better competitiveness and further organisational development.

The Deming Prize is the first and it is one of the highest awards for total quality management in the world. It was established in 1951 to honor American engineer Edward Deming who contributed greatly to Japan's society and economy. It was under the guidance of Japanese Union of Scientists and Engineers (JUSE).

With the law on quality improvement (Public Law 100-107) voted in Congress in 1987 a programme and award were established in order to increase consciousness about quality management and recognising American companies that have implemented successful quality management systems. The Congress established, in 1987, a programme and a prize for raising awareness about quality

management and recognition of US companies that implemented successful 
quality management systems.Malcolm Baldrige National Quality Award, named after Malcolm Baldrige, Secretary of Commerce (1981-1987), is awarded every year by the president of the United States of America.

On the territory of Europe EFQM (European Foundation for Quality Management)model of business excellence was promoted by the European Foundation for Quality Management. This model will in 1992 be a framework for European Quality Award (EQA) which is, like Deming Prize in Japan and Malcolm Baldrige in the USA, awarded every year.

\subsection{Six Sigma and quality process improvement}

The methodology Six Sigma was developed and applied for the first time in Motorola Company in 1982 (Antony 2002, pp. 6-8). The philosophy of the concept Six Sigma is based on the understanding that a company can provide competence, and therefore competitiveness with the reduction in defects. The defect is everything that does not fulfill expectations or demands of the customers or business processes. Six Sigma is primarily oriented towards processes, and not results because the results are determined by what is happening during the process. Creating better processes eliminates possibilities for the occurrence of defects (Anđelković, 2004, pp. 132-138)

Methodology of Six Sigma concept implies that the improvement process, known as DMAIC process follows the following phases:(Bošković, Anđelković-Pešić, 2011, pg. 72)

- Define

- Measure

- Analyse

- Improve

- Control

\subsection{Lean and quality process improvement}

Lean concept is a set of efficient and rational procedures with principles, methods and tools, detects and eliminates useless activities (losses and mistakes) that do not add value to business processes. With their detection and elimination, on the level of an organisational unit, but also in industrial systems, there is the increase in the general work efficiency: costs are reduced, there is a reduction of operational cycles, of production cycle, of material flows, stock levels, and the increase of operational readiness, etc. (Radosavljević et al. 2015 pp. 284). 


\subsection{ISO 9000 and quality process improvement}

ISO 9000 series of standards led to greater awareness of the quality and its embedding into all processes on all levels of a company. ISO standards have laid the foundation and created conditions for the standardisation that enables comparison between companies, and monitoring performances of a company over a period of time. However, it is very important that gaining a certification from a series of ISO standards is not enough for great achievements (Kalač, 2014., pg. 7).

Standard ISO 9001:2015, as well as previous versions, is based on the process approach. The emphasis is on the adoption of the process approach in all segments of organisation management which improves effectiveness and efficiency of the quality system management and thus fulfills users` needs and demands and increases their satisfaction. It is essential to understand interrelated processes within a system and their management that are defined by quality politics and strategic direction of the organisation.

The process approach in the quality system management enables:

a) understanding the needs and consistence in their fulfillment;

b) consideration of the process in terms of added value;

c) achieving effective process performance;

d) improving the process based on the evaluation of data and information

(SRPSISO 9001:2015 p. 10).

Figure 1. - Graph of an element in a process

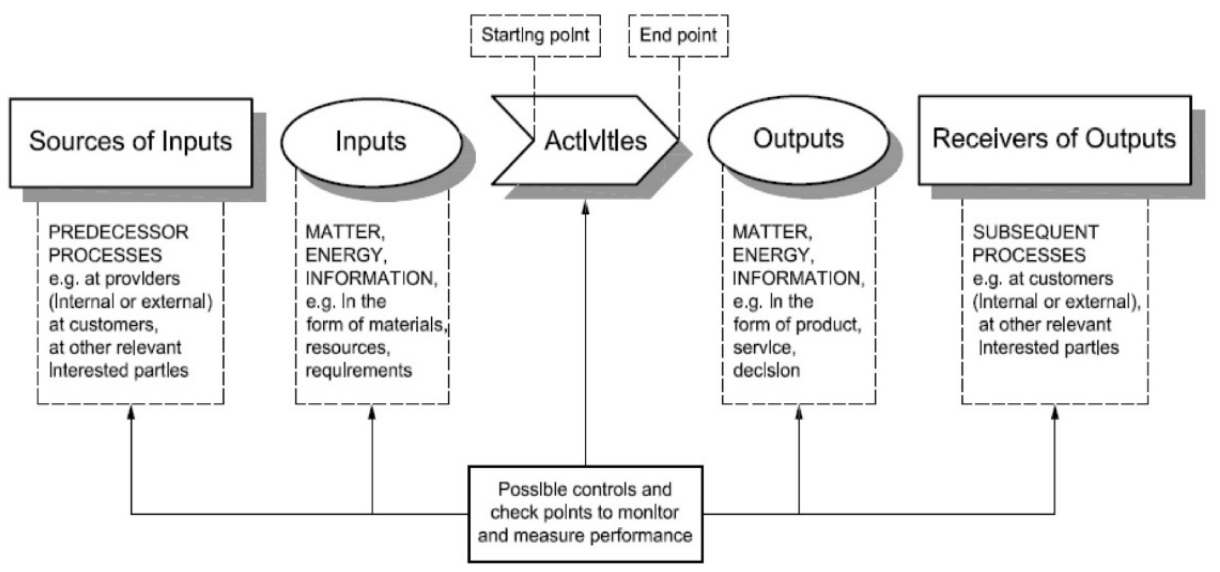

Source: SRPS ISO 9001:2015 pg.12. 
A graph of any process is shown in Figure 1. This graph shows the relationships between elements, and control points in which monitoring and measurement of the activities is performed. It is important to mention that monitoring and measuring of the activities in control points is specific for each process and that there will be differences depending on the risk that is related to a specific activity.

According to the requirements of this international standard, an organisation must establish, implement, maintain and constantly improve quality management system. This is achieved through process management and their interaction.

The organisation must determine which processes are required for the quality management system, their application in the organisation and needs to: (ISO SRPS 9001:2015 point 4.4, pg. 20):

- determine process inputs and outputs;

- determine the sequence and interaction of processes;

- determine the criteria and methods needed to provide an efficient functioning of these processes and their management;

- determine and ensure the resources needed to support processes;

- assign process responsibilities and authorities;

- plan and implement actions to address these risks, subclause 6.1;

- evaluate processes and if necessary modify them;

- improve processes and quality management system.

A continual improvement of the process and the system as a whole, within ISO standards 9001:2015, is achieved with the application of PDCA cycle with the focus on 'thinking based on the risk' in order to use opportunities and prevent unwanted results.

A brief summary of PDCA cycle:

- Plan: Defining the goals of the system, all individual processes, and the resources needed to achieve results in accordance with user requirements and policies of the organisation, along with identifying risks and opportunities;

- Do: apply what is planned.

- Check: monitor and measure the process and the resulting products, along with regular reporting of results.

- Act: taking measures to improve performance, if necessary.

Requirements set in 9001:2015, PDCA cycle can be applied to all processes and to the quality management system as a whole. Figure 2 illustrates how clauses 4 to 10 can be grouped in relation to ISO 9001:2015 in the PDCA cycle. 
Figure 2. - Representation of the structure of the international standard ISO

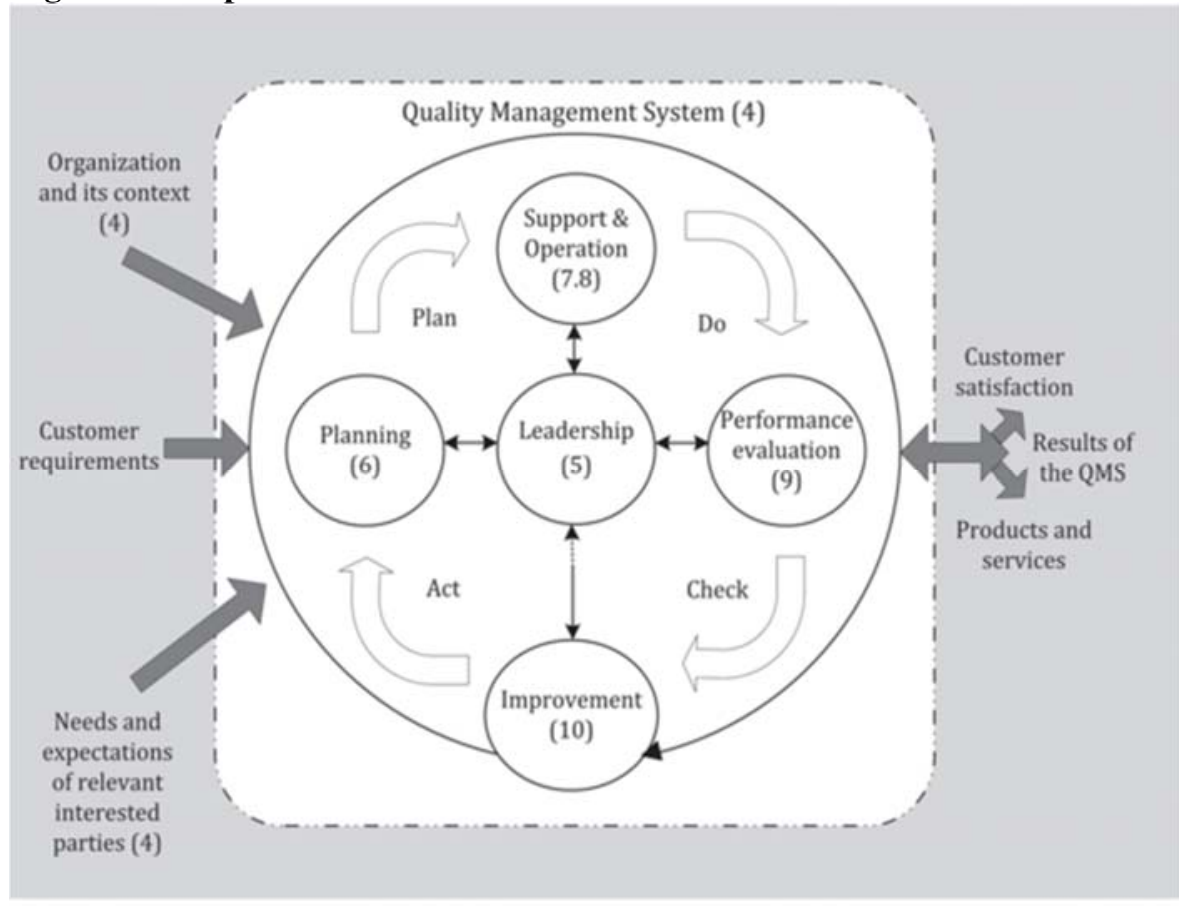

NOTE Numbers in brackets refer to the clauses in this International Standard.

Source: SRPS ISO 9001:2015,pg. 14.

For the functioning of the process of continuous improvement, it is necessary to integrate the quality values into a whole structure of the organisation because it requires full participation and commitment of all employees. Continuous improvement of business processes should contribute to increasing the efficiency, profitability and productivity of their development. In this way, it directly influences the improvement of the overall performance of the organisation.

\section{Quality process improvement - empirical research}

\subsection{Research methodology}

The research has been conducted on the stratified sample of 15 companies. The criteria for the choice of milk companies from which we have gathered information, have been their importance on the raw milk market, installed production capacities and their position on regional markets of milk processing and dairy products market. It was also necessary to ensure that gathered 
information of these chosen milk companies show a representative sample, and that they are significant from the aspect of their participation in the aggregate data on the total amount of sold and processed milk in the Republic of Serbia.

Stratification considers the representative number of milk companies in each of three stratums. Stratums are divided according to their market share, installed capacities and number of employees into three groups of milk companies: 'large', 'middle' and 'small' with the total market share between $70-80 \%$.

The research has been conducted according to a structured Questionnaire (Appendix 1) that has three parts. The first part includes general information about the company and the respondents who are employed in the company. The second part includes information about the implemented quality management systems, while the third part contains questions regarding business process management and methods and techniques employed for the continual process improvement. In the third part of the questionnaire, Likert 5 point scale was used where 1 means that the statement is wrong, while 5 means that it is absolutely right.

\subsection{Research results and discussion}

Based on the research related to the second part of the questions, the information about implemented quality management systems, the following results were gathered, and they are graphically represented.

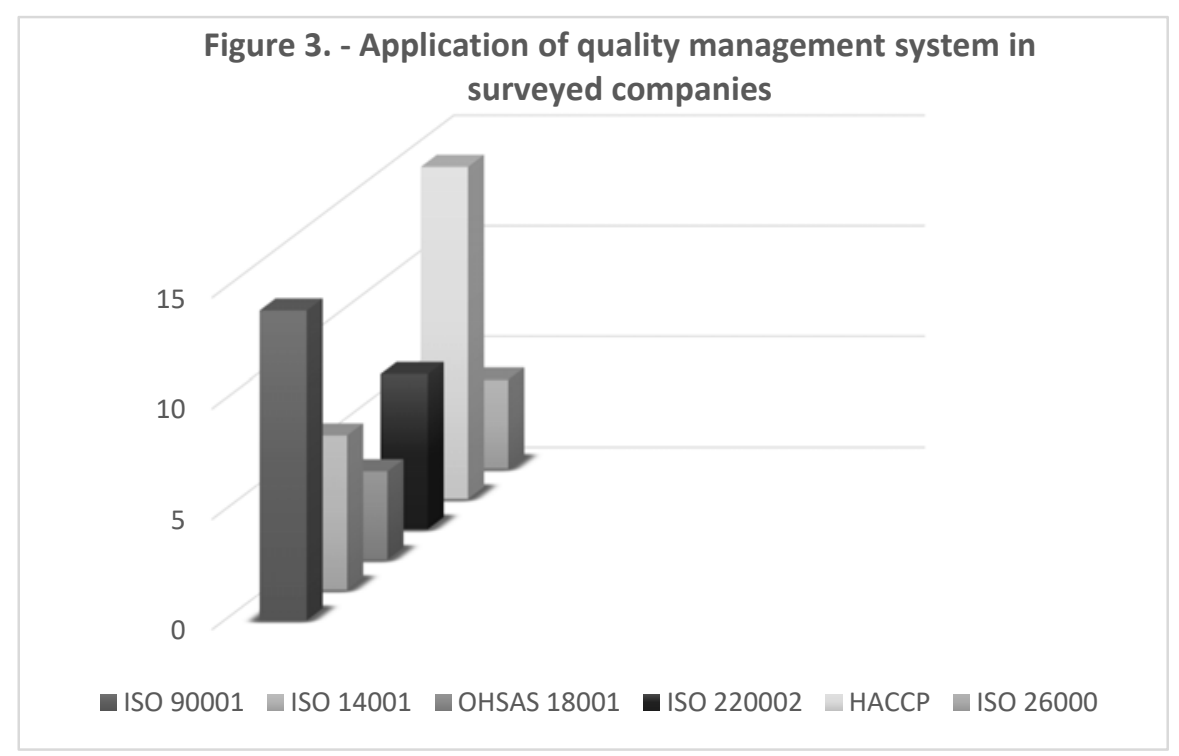

Source: Author`s research 
According to the theme of this paper, only results gathered from the research that relate to the methods and techniques of quality process improvement will be shown in further text. The research showed that the most frequently used method is the method of the continual process improvement according to PDCA cycle. Determined average value of the implementation of PDCA cycle method is 4.333. The second place is occupied by the visual representation of the process with flow diagrams with the average value of 2.667. Other methods and techniques of quality process management are either not applied or are insignificant. Unfortunately, the overall average value of the implementation of methods and techniques for quality process improvement received according to the average value of all methods is only 1.370 .

The results received with the statistical and descriptive analysis show a significant implementation of PDCA cycle as a method for the continual business process improvement. This is due to the growing presence of implemented quality management systems according to ISO standard 9001, as well as other standards that support this methodology (ISO 14001, ISO 22000). The use of other methods and techniques for business process improvement, except for visual representation of the process with flow diagrams and the statistical method of process control is almost nonexistent. This tells us about a very small number of methods and techniques that are implemented in the quality process improvement.

This research has also found that there is a big difference between the implementation of methods and techniques of quality process improvement, the implementation of a strategy, process management, continual improvement, and performance measurement between companies from the first stratum ('large milk companies') and the third stratum ('small milk companies'). The variance analysis has shown that it is necessary to accept the hypothesis that there is a difference in the implementation between subclasses (the sizes of milk companies). These three groups of milk companies differ according to the presence of methods and techniques of quality process improvement. It may be concluded then that the presence of methods and techniques of quality process improvement is positively reflected on the development and competitiveness of companies in the milk industry.

\section{Conclusion}

Companies that have implemented management based on the processes with the help of quality management systems have a huge potential for further development. In order to realise their potential, employees, and especially managers in companies, must possess a certain level of knowledge, skills and training, and must be encouraged by their management in order to adopt these two concepts. The implementation of the approach based on process management and quality management will make employees face many challenges. First of all, 
they must know customers' demands, determine processes that are crucial for providing a required level of quality, and then find adequate solutions for business process execution and perform a continual quality business process improvement.

This study has pointed out similarities of the basic characteristics of these two approaches, and their complementarity which enables the creation of an integrated concept. The aim of the integrated concept is to provide a competitive advantage through many quality improvements and prompt realisation of the key processes which, finally, lead to better financial results of the company.

In the companies of milk industry in the Republic of Serbia the tools that these approaches suggest are not sufficiently implemented. More precisely, there is a great disproportion in the implementation of the approach between a few 'large' systems and a great number of 'small producers. Due to a positive experience in accepting the principle that guides the mentioned approaches, as well as due to the possibility of accomplishing synergetic effects, a training in implementing methods and techniques for managers and all employees is strongly suggested in order to improve process quality and accept the elements of the integrated approach.

\section{References}

Ahmadi S A A., Aliahmadi A., Zahedi S., Aboonabi A., (2015) A process-oriented organization creation and retention model and its relation with planning school formation (case study: Iran Khodro CO.) International Journal of Asian Social Science, vol. 5(10), ISSN(e): 2224-4441/ISSN(p): 2226-5139 pg 599-610

Anđelković, (2004), Kao nemilosrdan zahtev za perfektnošću Ekonomika preduzeća Mart April 2004 str. 132-138.

Anđelković Pešić M., (2010), SixSigma: Metodologija za unapređenje procesa, Vrnjačka Banja, SaTCIPd.o.o.

Antony J., (2002) Design for Six Sigma: A Breaktrough Business Improvement strategy for Achieving competetive Advantage Work Study Vol. 51 No 1 pg 6-8

Bider I., (2005), Choosing Approach to Business Process Modeling - Practical Perspective, Inconcept issue 34.

Bosilj-Vukšić V., Spremić M.Omazić M. A.,Vidović M., Hernaus T.,(2006) Menadžment poslovnih procesa i znanja u hrvatskim poduzećima Ekonomski fakultet - Zagreb Sveučilište u Zagrebu, Zagreb

Bošković G., Anđelković-Pešić M., (2011) Upravljanje kvalitetom - osnova konkurentnosti preduzeća i privrede, Ekonmski fakultet, Niš.

Dahlgaard-Park, S. (2011). The quality movement: Where are you going?.Total Quality Management \& Business Excellence, 22(5), 493-516. doi: $10.1080 / 14783363.2011 .578481$ 
De Oliveira, P., Ladeira, M. B., McCormack, K., "The Supply Chain Process Management Maturity Model - SCPM3”, Supply Chain Management - Pathways for Research and Practice, 201-218. http://cdn.intechopen.com/pdfs/17153/InTechThe_supply_chain_process_manag ement_maturity_model_scpm3.pdf, assessed 11.04.2018.

Dumas, M., La Rosa, M., Mendling, J., \& Reijers, H. A. (2013). Fundamentals of business process management (Vol. 1, p. 2). Heidelberg: Springer.

Galbraith J.R. (2002) Designing Organisations: An Executive guide to strategy structure and process, Jossey-Bass, San Francisco, pg. 38

George S., Weimerskirch A., (1994) Total Quality Management - Strategies and Techniques Proven at Today's Most Successful Companies, John Wiley \& Sons, New York.

Institute of Management Accountants, (2000), Implementing Process Management for Improving Products and Services, Montvale, Institute of Management Accountants, p. 30-33.

Jeston, J. (2014). Business process management. Routledge.

Kalač E., (2014) Primena evropskog modela poslovne izvrsnosti u cilju unapređenja konkurentnosti malih i srednjih preduzeća, Univerzitet u Nišu, Ekonomski fakultet, Niš.

Radosavljević M. (2015) Procesna orijentacija kao osnov povećanja

zrelosti upravljanja lancem snabdevanja Ekonomske teme 53 (3): 407-423.

Radosavljević M., Bošković G., Mihajlović M., (2015).Procesna orijentacija kao karika između upravljanja ukupnim kvalitetom I lean menadžmenta, Poslovna ekonomija, 16, 277-294.

SRPS ISO 9000:2015 (2015). Sistemi menadžmenta kvalitetom — Osnove i rečnik, Institut za Standardizaciju Srbije, Beograd.

http://forleadership.org/wp-content/uploads/Competitive-Advantage.pdf

\section{METODE I TEHNIKE UNAPREĐENJA KVALITETA PROCESA NA PRIMERU INDUSTRIJE MLEKA U REPUBLICI SRBIJI}

Apstrakt: Dugogodišnje prisustvo procesne orijentacije u ekonomskoj teoriji i praksi pokazuje njenu korisnost za ostvarenje ciljeva preduzeća i njegovih stejkholdera. Međutim, sa druge strane, to ne znači da u ovoj oblasti nema prostora za unapređenje. Naprotiv, kontekst u kome preduzeća posluju se značajno menja, gotovo na dnevnoj osnovi, te treba tražiti nove načine za unapređenje procesa kako bi se odgovorilo sadašnjim ali i budućim zahtevima korisnika. Osnovni ciljevi ovog rada jesu definisati koncepte vezane za poslovne procese, upravljanje poslovnim procesima i istražiti primenu metoda i tehnika kontinuiranog poboljšavanja procesa i sistema upravljanja $u$ celini. Zatim, istražiti primenu metoda i tehnika unapređenja kvaliteta procesa $u$ preduzećima industrije mleka u Republici Srbiji, sa polaznom hipotezom da unapređenje kvaliteta procesa direktno utiče na konkurentsku poziciju preduzeća. Za teorijski deo rada korištena je relevantna literatura iz oblasti upravljanja procesima i oblasti 
upravljanja kvalitetom, dok je za empirijski deo rada korišćen strukturirani anketni upitnik na osnovu koga je sprovedeno istraživanje. $\mathrm{Na}$ osnovu analize podataka dobijenih istraživanjem došlo se do zaključka da se u preduzećima industrije mleka $u$ Republici Srbiji za unapređenje kvaliteta poslovnih procesa dominantno koristi metoda zasnovana na PDCA ciklusu

Ključne reči: proces, kvalitet, PDCA ciklus, upravljanje procesima, kontinuirano poboljšanje, procesna orijentacija.

\section{Author's biography}

Milan Mihajlović is a PhD student (field: Economy) at the University of Niš, Faculty of Economics. He is employed as teaching assistant on the Faculty of Business Economics and Faculty of Applied Security at the Educons University on subjects: Economics of the European Union, Principles of management, Strategic Management, Principles of economics. Furthermore, he is engaged as a researcher on 2 projects of Provincial Secretariat for Higher Education and Scientific Research Autonomous Province of Vojvodina. He is an author and co-author of 1 M21, 3 M23 papers, 1 M24 papers, 6 M33 1 M34 publications and 6 papers M51 1 M53 category. Also, he is working as a Secretary of the editorial board of Scientific magazine BUSINESS ECONOMICS magazine for business economics, entrepreneurship and finance. 